\title{
From Policy to Practice: Exploring Practitioners' Perspectives on Social Enterprise Policy Claims
}

\author{
Micaela $\operatorname{Mazzei}^{1}$ (D) Michael J. Roy ${ }^{1}$
}

Published online: 17 March 2017

(C) The Author(s) 2017. This article is an open access publication

\begin{abstract}
While there has been significant academic focus on social enterprise policy for a number of years now, the links between policy and the practice of social enterprise have received comparatively less attention. Scotland is recognised as having a particularly supportive environment for social enterprise; the Scottish Government has publicly endorsed social enterprise and made considerable investment into the sector. Based upon an in-depth qualitative analysis of the perceptions of social enterprise practitioners and stakeholders across Scotland, we explore whether the rhetoric of support matches practitioners experience of 'doing' social enterprise. Reviewing emerging issues and reflecting upon the complex nature of the Scottish context, including in relation to welfare reform, we find that in contrast to the claims of politicians, the attitude of local authorities in Scotland, coupled with a lack of understanding of the needs and requirements of social enterprise at the local authority level, has led to a rather more 'patchwork' picture than the rhetoric would seem to suggest. While some local authorities recognise the potential of social enterprise for their local economies and privilege and encourage cooperation, others are less inclined to openly support social enterprise, particularly those that are small in scale. Underpinning these contentions, we argue, are unrealistic expectations about the prospects of social enterprises being able to become 'sustainable', and how this could be achieved.
\end{abstract}

Résumé Même si la recherche a fortement étudié les politiques d'entreprise sociale pendant plusieurs années, les liens entre les politiques et la pratique ont été négligés en comparaison. L'Écosse est reconnue comme ayant un environnement particulièrement favorable aux entreprises sociales; le gouvernement écossais les a

Micaela Mazzei

micaela.mazzei@gcu.ac.uk

1 Yunus Centre for Social Business and Health, Glasgow Caledonian University, Cowcaddens Road, Glasgow G4 0BA, UK 
publiquement endossées et a fait des investissements considérables dans le secteur. Selon une analyse qualitative approfondie de la perception des spécialistes et intervenants des entreprises sociales de l'Écosse, nous tentons de découvrir si la rhétorique du soutien correspond à l'expérience que les intéressés en ont. En étudiant les enjeux en émergence et en réfléchissant à la nature complexe du contexte écossais, y compris dans le contexte de la réforme de la protection sociale, nous découvrons que contrairement aux affirmations des politiciens, l'attitude des autorités en Écosse, associée à un manque de compréhension des besoins et exigences des entreprises sociales au niveau des autorités locales, a dessiné une image plus «bigarrée » que celle suggérée par la rhétorique. Alors que des autorités locales reconnaissent le potentiel des entreprises sociales pour leur économie et privilégient et encouragent la coopération, d'autres sont moins disposées à les soutenir ouvertement, surtout si elles sont petites. Nous avançons que des attentes irréalistes concernant les perspectives de « durabilité » des entreprises sociales et la façon d'y arriver étayent ces divergences.

Zusammenfassung Während die Politik im Zusammenhang mit Sozialunternehmen seit nunmehr einigen Jahren im akademischen Fokus steht, hat man den Verbindungen zwischen Politik und der Praxis der Sozialunternehmen vergleichsweise wenig Aufmerksamkeit geschenkt. Schottland gilt als ein Land, dass Sozialunternehmen ein besonders förderliches Umfeld bietet. Die schottische Regierung hat Sozialunternehmen öffentlich ihre Unterstützung erklärt und beträchtliche Investitionen in den Sektor getätigt. Beruhend auf einer detaillierten qualitativen Analyse der Wahrnehmungen von Praktikern aus Sozialunternehmen und von Stakeholdern der Sozialunternehmen in ganz Schottland erforschen wir, ob die Rhetorik der Unterstützung den praktischen Erfahrungen der Praktikern aus Sozialunternehmen entspricht. Wir prüfen aufkeimende Probleme und stellen Überlegungen zum komplexen Charakter Schottlands an, unter anderem in Bezug auf die Reform des Sozialsystems. Wir kommen zu dem Ergebnis, dass im Gegensatz zu den Behauptungen der Politiker, die Einstellung der Kommunalbehörden in Schottland, einhergehend mit einem fehlenden Verständnis der Bedürfnisse und Erfordernisse von Sozialunternehmen auf der kommunalen Ebene, mehr zu einem „Flickwerk"geführt hat als die Rhetorik vermuten lässt. Während einige Kommunalbehörden das Potenzial von Sozialunternehmen für ihre lokale Wirtschaft erkennen und eine Kooperation bevorzugen und anregen, sind andere weniger dazu geneigt, Sozialunternehmen öffentlich zu unterstützen, insbesondere die kleineren Unternehmen. Wir behaupten, dass unrealistische Erwartungen hinsichtlich der Erfolgsaussichten der Sozialunternehmen, sich zu „nachhaltigen“Organisationen zu entwickeln, und hinsichtlich dazu, wie dies erreicht werden kann, diese Konflikte vertiefen.

Resumen Aunque ha habido un enfoque académico significativo sobre política de la empresa social durante una serie de años, los vínculos entre política y la práctica de la empresa social ha recibido menos atención comparativamente. Se reconoce que Escocia tiene un entorno particularmente favorable para la empresa social; el gobierno escocés ha apoyado públicamente a la empresa social y ha realizado una inversión 
considerable en el sector. Basándonos en un análisis cualitativo en profundidad de las percepciones de los profesionales y las partes interesadas de la empresa social en Escocia, exploramos si la retórica de apoyo coincide con la experiencia de los profesionales de 'hacer' empresa social. Revisando cuestiones emergentes y reflexionando sobre la compleja naturaleza del contexto escocés, incluso en relación con la reforma del bienestar, encontramos que, en contraste con los alegatos de los políticos, la actitud de las autoridades locales en Escocia, asociada a una falta de comprensión de las necesidades y requisitos de la empresa social a nivel de la autoridad local, ha llevado a un cuadro bastante más 'patchwork' que lo que la retórica parecería sugerir. Aunque algunas autoridades locales reconocen el potencial de la empresa social para sus economías locales y privilegian y alientan la cooperación, otras están menos inclinadas a apoyar abiertamente a la empresa social, en particular aquellas que son pequeñas en escala. Pensamos que, respaldando estas disputas, hay expectativas no realistas sobre las perspectivas de que las empresas sociales puedan llegar a ser 'sostenibles', y cómo podría lograrse esto.

Keywords Social enterprise $\cdot$ Devolution $\cdot$ Local government $\cdot$ Policy $\cdot$ UK

\section{Introduction}

The role of the social enterprise - an organisation that sells goods and services with an explicit social mission, rather than the maximisation of returns to investors or shareholders - as a tool of public policy is well documented. The 'hybrid' nature (Billis 2010; Doherty et al. 2014) of social enterprise arguably makes it ideally equipped to act as an instrument of political parties from each side of the political divide. From those who favour neoliberal, market-based approaches (Grenier 2009; Teasdale 2012) to those who believe in co-production, mutualism and partnership is building between the Third Sector-the space between state and market (Salamon and Sokolowski 2016) - and government (see, for example, Farmer et al. 2012; Pestoff 2012, 2014). This 'schizophrenic' or chameleon-like nature of social enterprise seems to offer significant utility as a policy tool, while also providing social enterprises with a tactical advantage to position them favourably: for example, to lever resources from government as political context and policy priorities change over time (Dey and Teasdale 2016).

Governments around the world have focused on the contribution of social enterprises to deliver a range of welfare services. However, less attention has been placed on how institutional demands and intentions are met by practitioners (Coule and Bennett 2016) in the context of delivering policy objectives. Furthermore, whether endorsement at the national strategic level has influenced, positively or negatively, the experiences of social enterprise practitioners to carry out their work, particularly at a local level, is yet to be substantively explored. This paper attempts to fill these gaps.

At a time when new welfare powers are being transferred to the Scottish Government from the Westminster-based UK Government, and devolution of political power is considered by many (see, for instance, Keating 2010) as a potential opportunity to attempt social policy innovation and differentiation (Scott 
and Wright 2012), we consider that Scotland provides an interesting context to review the connection between public policy and social enterprise. The Scottish Government has publicly endorsed social enterprise and made considerable investment into the sector. Moreover, the Scottish Government has attempted to plot a different (arguably more social democratic) course from the UK Government on a range of social policy areas, as will be discussed.

Through framing social enterprise in Scotland as an illustrative case study, we reflect on practitioners' perspectives on social enterprise policy claims. Building on the understanding of policymaking as a process of organisational interpretations and translations by diverse policy actors (Ball et al. 2011), this paper highlights some emerging concerns for a future Scottish welfare system. The paper is organised as follows: firstly, we outline the role of social enterprise in liberal welfare states, with a specific focus upon the politics (and policies) relevant to social enterprise in Scotland. We then discuss in detail the perceptions of social enterprise practitioners, particularly in relation to whether the seeming wealth of policy interventions dedicated to support and develop social enterprise in Scotland has produced a favourable environment for social enterprise, or whether there is a gap between policy rhetoric and practice. We conclude with presenting our own perspectives on why the Scottish case has resonance with, and relevance to, policy and practice internationally.

\section{The Role of Social Enterprise in Contemporary (Liberal) Welfare States}

Successive welfare reforms, emerging markets for welfare and increasing demands for a fairer economy (Ecchia and Lanzi 2003) have positioned social enterprise centrally in public policy and academic debates. The term social enterprise attempts to capture a variety of organisational and legal forms, with different ownership models and motivations driving their engagement in economic activities. The social enterprise research literature has long been concerned with understanding the relationship between public policy and social enterprise (see, for example, Laville et al. 2006) and therefore the role of social enterprise in contemporary societies. For some, the political interest in, and the case for, social enterprise is premised upon the conviction that traditional Western models of welfare provision are coming to an end (Peredo 2011), and that welfare states are unaffordable (Roper and Cheney 2005), bureaucratic and inefficient, and so unable to meet the social needs of citizens (Dees 1998). This functionalist and managerial account (Dey and Teasdale 2013) considers social enterprise inevitable, and public policy as the means through which the Third Sector can be transformed into a more efficient mechanism of addressing social needs. In policy terms, as noted by Hudson (2009) and Amin (2009), it is recognised and accepted that a 'third system' (Pearce 2003) should exist in parallel to state and market, sometimes overlapping with the mainstream economy through its market orientation (for example, consumer cooperative organisations) or through the absorption of state welfare functions (as the case with social cooperatives in Italy) (Amin 2009, p. 33). Conversely, in countries like the $\mathrm{UK}$, where liberalisation of the state is more advanced, the expectations are, 
increasingly, for social enterprises to be run as efficient businesses, providing quality (public) services at competitive prices (ibid). This is a cause for concern for some authors: Pearce (2003, p. 31), for example, insists that 'social enterprises may be absorbed into the value and practice frameworks of the other systems (private and public) and coupled to their purposes'. Critical responses have therefore tended to portray social enterprise as a tool redolent of the neoliberal agenda (Graefe 2005) to drive disinvestment in welfare services and promotion of market-based approaches to tackling social needs. For instance, social enterprise has been associated with advancing the 'marketisation' of the Third Sector (Dart 2004; Eikenberry and Kluver 2004; Haugh and Kitson 2007) and transforming Third Sector organisations into delivery agents (and thus a 'governable terrain') of the state (Carmel and Harlock 2008).

In the UK the label 'social enterprise' initially became popular during the New Labour Government in Westminster, where social enterprise policy was initially developed under the 'hyperactive mainstreaming' of Third Sector policy (Kendall 2009). This policy enthusiasm has been linked by Haugh and Kitson (2007) to the early adoption of a 'Third Way' agenda in the 1990s, by a government keen to plot a path between the competing ideologies of socialism and liberalism. In Scotland, however, the term 'social enterprise' was used far later, only appearing in the policy documents of the Scottish Labour Party at the very end of their administration in 2007 (Scottish Executive 2007) a full decade after Leadbeater's (1997) influential pamphlet The Rise of the Social Entrepreneur had influenced the Labour Party's agenda in England. Prior to this, the focus in Scotland had been on what was referred to as the 'voluntary sector' and subsequently the 'social economy' (Scottish Executive 2003). However, with the Scottish National Party (SNP) coming to power in Scotland from 2007 onwards, the language and focus of the Scottish Government changed.

\section{The Scottish Social Enterprise Landscape}

An early forerunner of social enterprise policy in Scotland was the support provided, particularly in the 1980s and 1990s, to the 'community business' (later 'community enterprise') movement. The idea was initially imported from Ireland into the highlands and islands of Scotland, and then into urban areas, particularly through the means of European funding (Roy et al. 2015; Pearce 1993, 2003). Some of these early community businesses still exist and thrive today. However, as mentioned, Scotland was slow compared to England in explicitly using the phrase 'social enterprise' in policy. Following their election initially as a minority government in Scotland in 2007, the SNP enthusiastically embraced what they initially described as the 'Enterprising Third Sector', and introduced a raft of initiatives and significant financial support (Scottish Government 2008) to build their own distinct 'Scottish approach' to social enterprise (Roy et al. 2015). Capitalising upon what the SNP recognise to be a long-standing tradition of mutuality and cooperativism, for example, the Scots-based utopian socialist reformer Robert Owen is even evoked in 
Scottish social enterprise policy, as paving the way 'for new forms of business, where social and commercial goals are blended together in the pursuit of a fairer and more equal society' (Scottish Government 2016, p. 4). It could be argued that social enterprise is 'performed' differently in Scotland than in many parts of England, with the 'community business' model (see Teasdale 2012) still the dominant mode. For example, Roy et al. (2015) argue that while the UK government adopted a broad and inclusive definition of social enterprise that is clearly market aligned (see Office of the Third Sector 2006), the Scottish experience has been more practitioner led, with SENSCOT (the Social Entrepreneurs Network for Scotland) leading the development of an operational definition which stresses the importance of values such as fairness and cooperation, which are arguably absent, or less dominant, in many parts of England where a US-style 'social entrepreneurship narrative' is more dominant (see Teasdale 2012).

Over the last decade or so, current Scottish Deputy First Minister, John Swinney MSP, has been shown to be particularly supportive of social enterprise. Immediately prior to an appearance at a conference in Norway, he said that

Scotland has been recognised as the best place in the world to start a social enterprise and there is increasing international interest in what some are calling the 'Scottish Model'... an enterprising third sector is a vital partner in our economy, in civic society and in the creation of a fairer and more inclusive Scotland (The Scotsman 2014, p. 1).

Described as 'thriving' in Scotland's Economic Strategy (Scottish Government 2015), according to the Social Enterprise Census $2015^{1}$ for Scotland, there are around 5199 social enterprises operating in the country (Social Value Lab 2015). They are found in greatest numbers in the urban neighbourhoods of lowland Scotland, where just over 4000 social enterprises are based. By contrast, there is a far greater density of social enterprises in the highlands and islands region of Scotland, with $>1$ social enterprise per 1000 people. The Scottish social enterprise community is dominated by very small organisations, with $60 \%$ having a turnover of less than $£ 100,000$. The net asset of Scotland's social enterprises is calculated to be of $£ 3.86$ billion with an estimated economic contribution of $£ 1.68$ billion gross value added (GVA). One quarter of all social enterprises active in Scotland were formed in the last five years and $42 \%^{2}$ in the last two decades. Reflecting the alignment with key areas of public policy, $45 \%$ of social enterprises in Scotland operate with the objective to 'create employment opportunities' (Social Value Lab 2015).

\footnotetext{
1 The Social Enterprise Census 2015 is a project endorsed by the main partners involved in the social economy in Scotland including the Big Lottery Fund, Community Enterprise in Scotland, Co-operative Development Scotland, Firstport, Highlands and Islands Enterprise, Glasgow Caledonian University, Nesta, Scottish Enterprise, Scottish Government, Scottish Urban Regeneration Forum, SENSCOT, Social Enterprise Academy, Social Enterprise Scotland, Social Enterprise UK, Social Firms Scotland and Social Investment Scotland. The research was carried out by Social Value Lab (www.socialvaluelab.org.uk).

2 This figure is based on the known age of 4490 of the 5199 identified SEs in Scotland (Social Value Lab 2015).
} 
There is a wide range of policy interventions aimed at supporting the development and finance of social enterprise in Scotland. Both Firstport and Business Gateway are prominent actors providing support for start-ups. Both focus on promoting businesses aiming to have a positive impact on the community or the environment by offering training, resources and business support, albeit that Business Gateway has traditionally focused attention on mainstream for-profit business. The Social Entrepreneurs Fund is managed by Firstport and provides finance to individual entrepreneurs to start up new social enterprises. The Enterprise Ready Fund provides grants to help new start-ups, and both emerging and established social enterprises become more self-sustaining and grow. The Scottish Investment Fund awards provide a mixture of grants, risk capital and loans, following successful application by Third Sector organisations.

The commitment to grow the social economy has been recently renewed, when in December 2016 the Scottish Government launched a ten-year social enterprise strategy, which was developed in partnership with the sector and provides a framework for action over the next decade. ${ }^{3}$ The Scottish Government also continues to fund a considerable number of support agencies to sustain social enterprise development and operations, most notably SENSCOT, Social Enterprise Scotland and Social Firms Scotland through a 'Supporting Social Enterprise' partnership. The Scottish Government pays considerable attention to the support requirements of social enterprises and fund sector bodies that facilitate help and support for social enterprises. These are often organised at a local or Scotland-wide level. SENSCOT, for example, has the objective of supporting social entrepreneurs and their ventures, and which organises several thematic and geographic 'SENs' (social enterprise networks). Other noteworthy examples of public sector support include: the government's support for Ready for Business, 'an innovative partnership between third-sector and private-sector organisations, which aims to scale up social enterprises and voluntary charities in Scotland by supporting the development of public social partnerships' (OECD 2016, p. 8); and Just Enterprise, a consortium that helps social enterprises bid for a specific project. The government also supports Community Enterprise in Scotland (CEIS), a large social enterprise support agency based in Glasgow which specialises in delivering training, support and investment programmes.

In the light of increased social policy powers becoming effective through the Scotland Act 2016, some scholars (for example, Sinclair and McKendrick 2012) see potential for a new welfare settlement that reflects a distinctly Scottish approach to achieving social justice. Others (for example Rummery and McAngus 2015) are less convinced about the likelihood of a distinctly different welfare state developing in Scotland. Reflecting upon social enterprise policy development and sustainability in relation to welfare change provides an interesting lens through which to consider the potential for a new Scottish welfare regime. While the Scottish Government has openly and emphatically publicly endorsed social enterprise and has also made considerable investment into the sector, whether this support translates into practice requires further examination. If there is a particularly enabling social enterprise

\footnotetext{
3 http://www.gov.scot/Publications/2016/12/4404/downloads.
} 
'ecosystem' (Hazenberg et al. 2016) in Scotland, then what might be the consequences for the nascent Scottish welfare system, in both positive and negative terms? And what are the practical consequences of such a policy focus?

\section{Methodology}

Our study is undertaken in the spirit of Dunleavy's (1981) assertion that much of policy, in the end, is 'what professionals do in the field'. However, rather than professionals to mean public servants, we sought to understand the perspectives of practitioners in social enterprises as collaborative partners for innovation and improvisation within the policy process (Laws and Hajer 2006). We therefore base our understanding of policymaking as a process of organisational interpretations and translations by networks of diverse policy actors (Ball and Exley 2010; Ball et al. 2011). Given the changing nature of welfare, and the introduction of markets and voluntary and community sector actors into welfare provision in the UK in recent decades, we consider that social enterprise policy provides a useful lens through which to examine such matters.

The evidence presented in this paper is drawn from data collected in Scotland as part of a large-scale mixed method European Commission-funded research programme involving 11 countries across Europe. The overall aim of the project is to understand the conditions under which social enterprise develops and to assess whether such initiatives offer a sustainable contribution to addressing societal challenges. The data underpinning this paper emerge from a review of the literature and policy background on social enterprise in Scotland (considering relevant UK and European Union factors), and two focus groups held with practitioners. The first of these focus groups was held in Glasgow and involved representatives of the city's social enterprise community, while the second was held in Edinburgh and comprised representatives from a range regional infrastructure and support organisations. To collect the views from a (relatively) broad spectrum of social enterprises in Glasgow, organisations from different sectors of the local social economy were invited to take part in focus group discussions. In the first, six representatives participated. These were chief executives and/or founders of local organisations, of which two were established in relatively recent years and the others for more than a decade. The second focus group involved the participation of five representatives of intermediary organisations: agencies representing, developing and working with/for social enterprises across Scotland. Finally, a telephone interview was carried out with the representative of one organisation who was unable to attend the second focus group on the day it was held. The sampling process could thus be described as purposive, maximum variation sampling (Mason 2002) aimed at reflecting a plurality and wide heterogeneity of social enterprise forms and experiences (Mazzei 2016) in the city of Glasgow.

The process of data analysis commenced by reading through all the data, starting with the transcripts, and involved a process of thematic coding (Saldaña 2013). The themes emerged through an 'abductive' (Fann 1970; Kapitan 1992; Peirce 1932) process, involving 'moving backward and forward among empirical data, research 
literature, and emergent theory' (Dey and Teasdale 2013, p. 255). This iterative approach, known as 'systematic combining' (Dubois and Gadde 2002), allowed the emerging themes to be understood with reference to extant understanding of the literature, with the research team working together to discuss and code the data appropriately, including identifying inconsistencies, clarifying meanings and establishing additional emergent codes. The codes that were most pertinent to the topic were then further discussed among the team to draw out the key findings, which are discussed in the next section.

\section{Findings}

Confronting the narrative of official government publications with the opinions of those involved in delivering social enterprises, diverging perceptions of policy claims emerge. The conversations with social enterprises and their intermediaries highlighted several interrelated issues concerning the potential for social enterprise sustainability, which we have grouped into key themes, namely: inadequate procurement processes; stringent funding criteria; and scarce coordination of local infrastructure support. Recognised as barriers for social enterprise sustainability and contrasting the government's claims of as supportive environment for social enterprise development, each of these themes is discussed in turn.

\section{'Biased' Procurement Process: Misplaced Trust and Endorsement}

While the Scottish Government claims to recognise the contribution of social enterprises to the local economy-as exemplified in the Economic Strategy (2015) — when it comes to the tendering of public contracts, social enterprises do not consider that the environment for public procurement is especially favourable towards them. Participants to our research felt that if there was genuine government appreciation of the contribution of social enterprises to the local economy, then the social return and added value that social enterprises offer would be better taken account of within the public procurement process. In fact, practitioners claimed that funders were far more interested in the financial sustainability of a service, rather than its long-term effectiveness:

funders are all using this word sustainability, so how are you going to sustain the services after the money has gone? It forces you to being commercial, where actually they should look at the sustainability round about the services we are delivering. That is, social turn on that investment, saying 'do you know what, that is actually very good value for money', if the council delivered that it would be five times or three times as much (Focus group 1).

This lack of recognition is reflected in how public sector contracts are allocated and the procurement processes enacted, and was highlighted as a barrier to the sustainability of social enterprises. Participants felt that the procurement process was designed to privilege private-sector companies, mostly larger companies, where the unit of measure is cost and the requirement is a healthy balance sheet and cash- 
flow forecasts. These financial characteristics count as capacity for 'doing the job' and organisations are asked to compete on this basis. It was considered far more difficult to demonstrate the capacity to deliver when working with disadvantaged groups: what it is not reflected in the procurement documentation, they argued, is the considerable lengths that some organisations will go through to upskill people who have long been distanced and disadvantaged from the mainstream labour market:

[Councils] are not really putting enough thought into [contracting out services] so actually the effectiveness of it is not necessarily going to be demonstrated because the processes and the conditions or whatever they're putting in place are not really designed for social enterprises to thrive (Focus group 2).

it's that very, very first step of moving on, and then they can move on but the first step is getting people engaged, feeling confident, they can look people in the eyes, they can speak in sentences [...] But these other people [such as private companies and/or large social enterprises] are starting with people up here [indicating a high level of capacity] (Focus group 1).

One of the local authority stakeholders interviewed stated that the culture of both local authorities and social enterprises needed to change before procurement can be used as a mechanism for achieving significant impact. For example, public contracts-particularly those where there is a specific requirement to benefit the community - tend to be large in scale, favour bigger companies over smaller ones, and are simply too large to be relevant to the vast majority of social enterprises:

If in the long-term there are small contracts then small businesses will remain and small businesses and social enterprises will grow. If you make the contracts bigger and bigger, as is happening, [...] those small organisations will go, they will disappear (Business support stakeholder)

Overall, procurement processes were criticised for privileging larger-scale contracts (and thus organisations) over socially oriented organisations: many of the contracts are simply seen as being too large for small organisations and social enterprises to bid for, representing a significant financial risk to often cash-strapped organisations. In such a context, larger organisations can rely on economies of scale, allowing them to compete for larger contracts and manage administrative work efficiently. One of the financial stakeholders we interviewed suggested that government should allow for smaller contracts to be procured, since this would incentivise participation from a variety of social enterprises and small businesses. Indeed, one of the Business support stakeholders we interviewed suggested that the size of contracts should be reduced, and projects should be split into smaller tasks that could be handled by small businesses, many of which will be social enterprises:

If your turnover is only a hundred thousand pounds then you cannot go for a one million pound contract. (Business support stakeholder)

[...] If you don't look after the small ones, you'll only get swamped by big social enterprises, by big funded social enterprises that support companies and 
indeed by multinational commercial companies. (Business support stakeholder)

However, while reducing the size of some contracts may be beneficial for social enterprises, it could be argued that doing so may jeopardise an entire service for a number of reasons, including failure to deliver specific tasks by some of the organisations involved and differential quality of various service components.

Another element that has repercussions for the procurement process is austerity. Many stakeholders suggested that when financial resources are scarce, economic considerations - the so-called bottom line-takes far great precedence over other criteria. In general, the main indicator for evaluation in the procurement process is considered to be cost, rather than the social value of activities delivered. This was recognised as being even more focused since austerity has started to bite: council budgets have come under pressure, and it is recognised as being more difficult to argue for taking account of wider societal benefits. However, there was a general view among those we interviewed that when an explicit connection between procurement and local development is made, the role for local social enterprises in such an agenda becomes far more obvious.

From a local authority perspective, there were concerns around consistency, capacity and quality of delivery. One instrument adopted by local authorities to help overcome the problem of insufficient scale to support the delivery of services has been to promote the formation of consortia (such as under the ambit of Ready for Business, as previously mentioned) aimed at incentivising smaller organisations to collaborate, participate in procurement contracts and increase their influence through working together. In some cases, as noted by one of regional stakeholders we interviewed, particularly in the most remote parts of Scotland, communities come together in order to provide such services or to control the provision of services supplied by an external company.

There are, however, examples of cases - such as in the highlands and islands of Scotland-where contracts have been disaggregated and reduced in size, with the deliberate aim of privileging local provision and fostering local economic development. There was a view, however, that it is not a particularly sustainable strategy for social enterprises to be so focused upon public sector delivery. It was considered that brings the risk of social enterprises becoming too dependent upon a single source of income (that is, the state) and leaving their communities behind. For this reason, some stakeholders propose that the 'ecosystem' of organisations focused on delivering aspects of public policy should expand to take account of the role of other institutions, like banks and other investors:

I think we need to just diversify the way in which the ecosystem is talking about the importance of [public procurement] for social enterprises. But absolutely it should be an ambition that social enterprises should be delivering public sector contracts. (Financial stakeholder)

In summary, procurement is still an important issue that has not been tackled uniformly across Scotland. While the government adheres to European Union (EU) principles of inclusiveness for smaller and social enterprises, the outcomes seem to 
vary depending on the sociocultural peculiarities of certain local authorities (a point to which we shall return). Austerity has likely exacerbated the attention to the cost of service delivery and detrimentally impacted the ability of local authorities to take risks on providing contracts to smaller organisations, including social enterprises. This may have negative impacts in the future as austerity continues to bite, particularly in places that have a dearth of local providers, such as in many parts of the highlands and islands, where, least up until now, there has been willingness shown to promote smaller contracts to sustain local (social) enterprise.

\section{Funding Criteria Reflective of Need}

A further issue highlighted as a barrier to social enterprise sustainability was setting funding criteria that did not recognise the costs implied in delivering services for and with the most vulnerable people in society. Practitioners identified that it was difficult for them to cope with stringent criteria that set strict limits for when they had to deliver services by and also criteria which jeopardised their ability to generate income. Often, it was noted funding criteria are too restrictive about what money can be spent upon, thereby limiting the option of using part of it to develop something that could generate additional income and/or serve a specific identified need within the community. Many social enterprise practitioners felt that there was insufficient appreciation of what an organisation actually needs to deliver a service for disadvantaged people or other parts of the community: calculations on funding/contract allocations are mostly based on what can be delivered at a certain cost. Funded organisations thus barely covered their costs, with very little space for experimentation or genuine innovation. Interviewees recognised that subsidising social enterprises supporting the most vulnerable members of their communities is of critical importance, in line with the idea that it is the duty of society to help those most in need, and that citizens accepting a higher fiscal load is one of the ways to reach such an objective. Many social enterprises employ some of the most vulnerable members of society but require external financial assistance to do so if they are to remain financially viable. Some of the interviewees argued that it was important for citizens to accept higher taxes in order to subsidise essential community services. In particular, a Business support stakeholder recalled her experience working alongside many social enterprises with the objective of teaching them to be more enterprising and raise more money by themselves. Her conclusion, however, was that supporting vulnerable people can be so absorbing for social enterprises that it may, in fact, be unreasonable to expect them to engage in largescale fundraising activities:

There are various groups that we've worked where we've been brought into try and look at how they can be more enterprising, to raise more money through trading. And you think actually, they're so busy doing the day job of caring for very vulnerable folk that it's unreasonable and we should just all be paying more taxes to cover that. It's what a good society should be doing (Business support stakeholder). 
Moreover, it was considered that the duration of funding in European, national and local programmes can introduce a tension between the political funding cycle and the needs of social enterprises (and, indeed, of communities). There was no true appreciation, and it was claimed, of the length of time involved in making a genuine and substantive difference to the lives of people and communities, with social enterprises often bearing the burden of the short-term outlook of public sector spending:

another thing as well, and you will probably have come across it, if there is money to come from Europe, it will come in as a different form. It's just like government money, you don't know until somebody tells you it is European money. It always has a very short lifespan. You have got to spend this money by March, and this is like, October. And you are like 'we can't do that'... And that is coming from Europe; they are saying the European Commission say this has got to be spent. [...] This is silly, and they said 'no-this needs to be, you have to finish it'. And, I mean, because people are just spending the money, they get it and spend it, and [are] actually not getting the results (Focus group 1).

\section{Coordination of Local Support Infrastructure}

A final point that emerged from our research was the need for better coordination of the local infrastructure and support available to social enterprises. While there was seen to be numerous agencies providing support to social enterprises, often, it was argued that the advice was delivered by single consultants, who often come from a mainstream business background, such from banking. Their advice may be relevant to the commercial side of the organisation, but often have little appreciation or understanding of the wider social and/or environmental aims of the social enterprise.

'Third Sector Interfaces' were introduced by the Scottish Government several years ago to provide a single point of contact for voluntary, community and social enterprise organisations, organised at each local authority level. Their performance can vary considerably across Scotland. Indeed, there was widespread criticism of infrastructure bodies and their performance in general: many stakeholders lamented that most of the resources that the government has invested in social enterprise growth and development seem to have been absorbed by the support infrastructure, rather than being distributed to grassroot organisations themselves. As one stakeholder interviewed suggested:

The interesting piece of research there would be to look directly at where the government actually puts its money in towards social enterprise. And you will, I think, discover that an awful lot of it goes into the supporting organisations, support organisations based in Edinburgh and Glasgow. So Social Enterprise Scotland, Social Firms Scotland, DTAS [Development Trust Association Scotland], SCVO [Scottish Council for Voluntary Organisations], all of these organisations are receiving probably millions of pounds and none of it is actually getting down, core funded (Business support stakeholder). 
Participants in both focus groups also noted that while there are significant resources being provided by the Scottish Government for social enterprise, they questioned how these were being used. Many argued that there is a case for reviewing the focus of these resources and where they are directed:

I think there are a lot of resources coming out from the Scottish Government for the third sector. I think the review of the resources and how they're used is welcome because I think things are changing and some of the policy focuses are different. It will be interesting to see whether or not there are better ways in which those resources could be utilised and directed to reflect some of the changes in thinking than there has been in the past. So I'm not necessarily [saying] there needs to be more, I think it needs to be reviewed where it's focused and how it's directed. So in effect to reflect the policy directions which it doesn't really currently do (Focus group 2).

The perception of intermediaries was markedly different, however, in different geographical contexts, with a clear divide between perceptions of stakeholders in the highlands and islands of Scotland compared to those of other regional stakeholders. It became apparent that within the highlands and islands, the translation of regional and EU policies into local practice is considered effective and understood to be beneficial to the sustainability of local communities. The endorsement that social enterprise receives at the regional level is reflected in practice in the highlands and islands, with a clear recognition of the benefits that social enterprise activity can bring to small communities. There was also a marked difference reported in the level of cooperation between intermediaries and the Highland Council, for example, compared to relationships in certain cases in lowland Scotland.

\section{Reflections: Misconception of Need?}

Despite the recognition that Scotland offers an encouraging environment to social enterprise at the national policy level, a clear sense of disillusionment and cynicism was apparent concerning the difference between the rhetoric of politicians and the reality of everyday social enterprise practice. While the research underpinning this paper was not aimed at studying discourse per se, the themes emerging through our qualitative research stood in contrast to the optimistic messages emanating from governmental reports. This partly reflects practitioners' agency (Dey and Teasdale 2013) in implementing social enterprise according to their social realities rather than policymakers' claims. This also resonates with the work of Howorth et al. (2011) in England who found that the policy drive leads to a diverse application of the policy discourse in social enterprise. Indeed, sometimes the dominant promotional view is rejected by practitioners (Seanor and Meaton 2008) or used tactically (Dey and Teasdale 2016).

Our investigation highlighted that the rhetoric of policy documents is seldom reflected in the realities of practitioners, whose perceptions and comments reflect instead the relevance of historical and political legacies in shaping policy 
implementation at local level. Indeed, participants to our research presented a rather patchy picture. It was recognised that the Scottish Government fosters social enterprise through favourable legislation focusing on the development and potential sustainability of social enterprise in Scotland. For example, new forms of legislation are coming through empowering communities and also providing recommendations on how to deliver public services differently. However, participants felt that there was not adequate 'enforcement' of the Scottish Government's policy intentions at the local authority level. In practice, the proposed new legislation does not actually mean that the local authority will act more supportively:

part of the problem with those is, particularly the Empowerment Bill, it doesn't force local authorities to act differently. It gives communities the power to ask but there's no enforcement within it. It's [questionable] whether you could enforce it, but that's where its potential weakness is. It empowers the community but it doesn't entitle them (Focus group 2)

The consequence of this is a very mixed picture across the country: some authorities, particularly in the more rural parts of Scotland, were seen to be at the forefront of collaboration with their local communities and share service delivery. The highlands Western Isles and Orkney were all cited as examples of local authorities devolving power to the community level. However, it has also been noted that the very nature of their context calls for this type of approach, since 'logistically they couldn't do it [otherwise]' (Focus group 2).

In the northern islands (Shetland and Orkney) it was recognised that there was a clear aim to support community businesses that would otherwise disappear, with an obvious negative impact on the local socio-economy (Business support stakeholder). These islands are almost individual economies, self-sufficient but otherwise feeling connected to the UK, as reflected in the results of the 2014 independence referendum where most voted against independence (regional stakeholder). Such different approaches reflect different philosophies to supporting and driving different parts of the development of the social enterprise 'ecosystem'. As one of our interviewees noted:

Historically, Highlands and Islands Enterprise have been investing in social enterprises over the last 30 years. Their policies have been focused on developing community enterprises, which are an integral part of their ecosystem (Financial Stakeholder).

However, there is also perceived to be more resistance to social enterprise among some urban local authorities. Arguably, since most of the research has been carried out in Glasgow, it could be that there are peculiarities relating to this city. For a century, Scotland's largest city has been an 'Old Labour' stronghold and relationships with the Scottish Government, particularly since the SNP came to power in 2007, have been tumultuous at times. So, in some senses the disillusionment of social enterprises in Glasgow is not directed at the Scottish Government itself, nor necessarily in high-level policy per se, but the extent to which policies are translated and enacted (or not) at the local level. There can be 
considerable leeway in how local government officers interpret national policy; high-level guidance on procurement just being one example.

Partly, it is an issue of consistency of approach across larger urban local authorities, but partly there is also the fact that urban communities are less homogeneous than rural areas and can have multifaceted, often more acute, challenges:

I think it's difficult for local authorities because it's never going to be consistent, so every community and every community group are going to do things slightly differently. So if you're looking to approach the local authority to buy into something or to support something it's very difficult because it's not going to be the same every time. They're looking for an easy quick route through. I think they find it a bit messy, which also they find a bit scary because they can't just say here's the policy, here's the approach, sign it off and it will happen. So I think they find it a bit difficult to deal with (Focus group 2).

Ultimately, the extent to which national policies can be interpreted and implemented differs from place to place, reflecting the process of organisational interpretations and translations by diverse policy actors that is policymaking (Ball et al. 2011). This in turn has important implications for the relevance of this study to other contexts and how it relates to social enterprise policy development.

\section{Discussion}

The historical, cultural and political context in which organisations are situated shapes the ways in which policies are implemented locally (Mazzei 2016). This implies that considerations on the intersection between social enterprise policy claim and practitioners interpretations should be mindful of the 'power of place' (Amin et al. 2002). Those places that recognise the value of the social economy in developing the communities-like Highland and Island Enterprises-consider social enterprise as an important economic actor and thus translate national government policy into effective forms of collaboration. Conversely, in those contexts in which increased competition for shrinking resources and funding opportunities marginalise the social economy to an adjunct to mainstream, the implementation of national policies or-more accurately-enthusiasm is met with criticism as failing to recognise the real need. Ultimately, whatever the intentions behind the governmental push to support and develop social enterprise-whether progressive or instrumental-there are still some barriers that need to be overcome in order to obtain better conditions for potential sustainability as reflected in the misconceptions of funders about the needs of social enterprises and the ways in which the procurement process is enacted. We encountered unrealistic expectations about the prospects of social enterprises reaching sustainability and how this could be achieved, particularly if too much emphasis is placed upon their ability to operate within competitive markets than their wider contribution to community wellbeing. 
Reflecting upon this finding, we have argued that the attitude of some local authorities towards social enterprise, coupled with a lack of understanding of the needs and requirements of social enterprise at the local authority level, has led to a rather more 'patchwork' picture than the politicians' rhetoric would seem to suggest. This has important implications for the future of a distinctive Scottish welfare system. A number of policy-relevant suggestions emerge from these considerations. Firstly, greater recognition within the public procurement process of social impact, as opposed to a narrow focus on cost, would support social enterprise sustainability and contribute to a more level playing field between social enterprises and mainstream for-profit companies. In conjunction with this, increased scrutiny of policy implementation at the local level may help to overcome some of the disadvantages that social enterprises face, although admittedly others may arise in response. Problematic power relationships and struggles over service ownership and control will likely take longer to resolve and may have to involve a significant culture shift to embed at the local authority level, albeit that the political landscape in certain local authorities may be about to change. There also appears to be significant local discretion and variation in interpretation of legislation introduced to favour social enterprise activity, such as the Community Empowerment Bill mentioned previously, or indeed, the use of Community Benefit Clauses (CBCs) in public procurement, albeit that the effectiveness of CBCs is still to be determined. A recent evaluation (Sutherland et al. 2015) called for, among a range of recommendations, a more comprehensive evidence base to be developed to understand the longer-term impact of CBCs.

The evidence emerging from this paper suggests that there is a window of opportunity for Scotland, in utilising new welfare powers and thinking through the way they are enacted, to work collaboratively with social enterprises to enact a fairer diverse economy, complementing state and market provision. In specific circumstance social enterprises can achieve something truly distinctive (Hudson 2009)

\section{Conclusions}

In this study, we set out to reflect on practitioners' perspectives on policy claims, with a view to investigating how institutional demands and intentions are met in practice, building on the understanding of policymaking as a process of organisational interpretations and translations by diverse policy actors. Drawing on the findings of an illustrative case study in Scotland, we found several emerging concerns, all of which have wider implications for the understanding of the intersection between public policy and social enterprise.

Underpinning the diverse ways in which practitioners have enacted and implemented governmental rhetoric, the findings emerging from our research reveal that reality is often more complex than the binary opposition between instrumental and critical responses. The multifaceted ways in which practitioners react to, and enact, policy implementation reflect both their agency and the importance of cultural inputs and instituted practices as guidance in the 
understanding. This means that the perceived role of social enterprise varies from place to place, with implications for its potential and expectations. Policymakers have little control over this patchiness (Cairney et al. 2016); however, the Scottish Government has set out a clear message of recognition of social enterprise as an important actor in a diverse economy. In this way, that is if this recognition is symptomatic of increased co-produced policies, then arguably this potentially 'Scottish approach' (ibid) could help address many of the issue of uneven policy implementation.

Whether the increased welfare functions of the Scottish Government will represent a move from a liberal to a socio-democratic system remains to be seen. As, indeed, is the question of whether the 'patchiness' of policy implementation will help or hinder the process of embedding and delivering the new Scottish welfare system. It could be recognised that the support provided by the Scottish Government could be interpreted as a conscious attempt to link Scottish policy distinctiveness and reasons for devolution (and indeed arguments for independence) to sociodemocratic ideals, and this point deserves further attention in future work.

Acknowledgements The research underpinning this paper was part of the EFESEIIS (Enabling the Flourishing and the Evolution of Social Entrepreneurship for Inclusive and Innovative Societies) project funded by the European Union's Seventh Framework Programme for research, technological development and demonstration under Grant Agreement No 613179.

\section{Compliance with Ethical Standards}

Conflict of interest The authors declare that they have no conflict of interest.

Open Access This article is distributed under the terms of the Creative Commons Attribution 4.0 International License (http://creativecommons.org/licenses/by/4.0/), which permits unrestricted use, distribution, and reproduction in any medium, provided you give appropriate credit to the original author(s) and the source, provide a link to the Creative Commons license, and indicate if changes were made.

\section{References}

Amin, A. (2009). Locating the social economy. In A. Amin (Ed.), The social economy. International perspectives on economic solidarity (pp. 3-21). London: Zed Books.

Amin, A., Cameron, A., \& Hudson, R. (2002). Placing the social economy. New York: Routledge.

Ball, S., \& Exley, S. (2010). Making policy with 'good ideas': Policy networks and the 'intellectuals' of new labour. Journal of Education Policy, 25(2), 151-169.

Ball, S. J., Maguire, M., Braun, A., \& Hoskins, K. (2011). Policy actors: Doing policy work in schools. Discourse: Studies in the Cultural Politics of Education, 32(4), 625-639. doi:10.1080/01596306. 2011.601565.

Billis, D. (Ed.). (2010). Hybrid organizations and the third sector: Challenges for practice, theory and policy. Basingstoke: Palgrave Macmillan.

Cairney, P., Russell, S., \& St Denny, E. (2016). The "Scottish approach" to policy and policymaking: What issues are territorial and what are universal? Policy \& Politics, 44(3), 333-350. doi:10.1332/ $030557315 X 14353331264538$.

Carmel, E., \& Harlock, J. (2008). Instituting the "third sector" as a governable terrain: Partnership, performance and procurement in the UK. Policy and Politics, 36(2), 155-171. 
Coule, T. M., \& Bennett, E. (2016). Rhetoric, organizational category dynamics and institutional change: A study of the UK welfare state: Institutional change in the UK welfare state. Public Administration. doi: $10.1111 /$ padm. 12274 .

Dart, R. (2004). The legitimacy of social enterprise. Nonprofit Management and Leadership, 14, 411-424.

Dees, J. G. (1998). Enterprising no profit. What to do when traditional sources of funding fall short? Harvard Business Review, 76(1), 55-67.

Dey, P., \& Teasdale, S. (2013). Social enterprise and dis/identification. Administrative Theory \& Praxis, 35(2), 248-270.

Dey, P., \& Teasdale, S. (2016). The tactical mimicry of social enterprise strategies: Acting "as if" in the everyday life of third sector organizations. Organization, 23(4), 485-504. doi:10.1177/ 1350508415570689.

Doherty, B., Haugh, H., \& Lyon, F. (2014). Social enterprises as hybrid organizations: A review and research agenda. International Journal of Management Reviews, 16(4), 417-436. doi:10.1111/ijmr.12028.

Dubois, A., \& Gadde, L.-E. (2002). Systematic combining: An abductive approach to case research. Journal of Business Research, 55, 553-560.

Dunleavy, P. (1981). Professions and policy change: Notes towards a model of ideological corporatism. Public Administration Bulletin, 36, 3-16.

Ecchia, G., \& Lanzi, D. (2003). Introduzione: Quasi mercati e riforma del welfare, in Verso il mercato di qualita' sociale, G. Ecchia \& D. Lanzi (Eds.), AICCON, Le Giornate di Bertinoro per l'economia civile. http://www.aiccon.it/agenda_scheda.cfm?wid=520.

Eikenberry, A. M., \& Kluver, J. D. (2004). The marketization of the nonprofit sector: Civil society at risk? Public Administration Review, 64, 132-140.

Fann, K. T. (1970). Peirce's theory of abduction. Dordrecht: Springer.

Farmer, J., Hill, C., \& Muñoz, S.-A. (2012). Community co-production: Social enterprise in remote and rural communities. Cheltenham: Edward Elgar Publishing.

Graefe, P. (2005). Roll-out Neoliberalism and the social economy, paper prepared for the Annual Meeting of the Canadian Political Science Association, University of Western Ontario, June 2.

Grenier, P. (2009). Social entrepreneurship in the UK: From rhetoric to reality. In R. Ziegler (Ed.), An introduction to social entrepreneurship: Voices, preconditions, contexts (pp. 174-204). Cheltenham: Edward Elgar Publishing.

Haugh, H., \& Kitson, M. (2007). The third way and the third sector: New Labour's economic policy and the social economy. Cambridge Journal of Economics, 31(6), 973-994.

Hazenberg, R., Bajwa-Patel, M., Mazzei, M., Roy, M. J., \& Baglioni, S. (2016). A comparative overview of social enterprise "ecosystems" in scotland and england: An evolutionary perspective. International Review of Sociology, 26(2), 205-222. doi:10.1080/03906701.2016.1181395.

Howorth, C., Parkinson, C., \& MacDonald, M. (2011). Discursive chasms: An examination of the language and promotion of social enterprise. In A. Southern (Ed.), Enterprise, deprivation and social exclusion: The role of small business in addressing social and economic inequalities (pp. 249-260). London: Sage.

Hudson, R. (2009). Life on the edge: Navigating the competitive tensions between the 'social' and the 'economic' in the social economy and in its relations to the mainstream. Journal of Economic Geography, 9(4), 493-510.

Kapitan, T. (1992). Peirce and the autonomy of abductive reasoning. Erkenntnis, 37(1), 1-26.

Keating, M. J. (2010). The government of Scotland: Public policy making after devolution (2nd ed.). Edinburgh: Edinburgh University Press.

Kendall, J. (2009). The UK: Ingredients in a hyperactive horizontal policy environment. In J. Kendall (Ed.), Handbook on third sector policy in Europe: Multi-level processes and organized civil society (pp. 67-94). London: Edward Elgar Publishing.

Laville, J. L., Lemaitre, A., \& Nyssens, M. (2006). Public policies and social enterprise in Europe: The challenge of institutionalisation. In M. Nyseens (Ed.), Social Enterprise. At the crossroads of market, public policies and civil society (pp. 272-295). London: Routledge.

Laws, D., \& Hajer, M. (2006). Policy as practice. In M. Moran, M. Rein, \& R. E. Goodin (Eds.), The Oxford handbook of public policy (pp. 409-425). Oxford: Oxford University Press.

Leadbeater, C. (1997). The rise of the social entrepreneur. London: DEMOS.

Mason, J. (2002). Qualitative researching (2nd ed.). Thousand Oaks, CA: SAGE Publications.

Mazzei, M. (2016). Understanding difference: The importance of 'place' in the shaping of local social economies. VOLUNTAS: International Journal of Voluntary and Nonprofit Organizations. doi:10. 1007/s11266-016-9803-3. 
OECD (2016). Policy brief on scaling the impact of social enterprises: Policies for social entrepreneurship. European Union/OECD. http://www.oecd.org/cfe/leed/Policy-brief-Scaling-up-socialenterprises-EN.pdf. Accessed 21 September 2016.

Office of the Third Sector (2006). Social enterprise action plan: Scaling new heights. London: Cabinet Office. http://webarchive.nationalarchives.gov.uk/20070108124358/http://cabinetoffice.gov.uk/third_sector/ documents/social_enterprise/se_action_plan_\%202006.pdf. Accessed: 9 September 2016.

Pearce, J. (1993). At the heart of the community economy: Community enterprise in a changing world. London: Calouste Gulbenkian Foundation.

Pearce, J. (2003). Social enterprise in anytown. London: Calouste Gulbenkian Foundation.

Peirce, C. S. (1932). Collected papers of charles sanders peirce. Cambridge, MA: Belknap Press of Harvard University Press.

Peredo, A. M. (2011). Social entrepreneurship. In L.-P. Dana (Ed.), International encyclopedia of entrepreneurship (pp. 410-414). Cheltenham: Edward Elgar.

Pestoff, V. (2012). Hybridity and the third sector: The coproduction of public services. Stockholm: Institute for Civil Society Studies, Ersta Skondal University College.

Pestoff, V. (2014). Collective action and the sustainability of co-production. Public Management Review, 16(3), 383-401.

Roper, J., \& Cheney, G. (2005). Leadership, learning and human resource management: The meanings of social entrepreneurship today. Corporate Governance, 5(3), 95-104.

Roy, M. J., McHugh, N., Huckfield, L., Kay, A., \& Donaldson, C. (2015). The most supportive environment in the world? tracing the development of an institutional "ecosystem" for social enterprise. Voluntas: International Journal of Voluntary and Nonprofit Organizations, 26, 777-800. doi:10.1007/s11266-014-9459-9.

Rummery, K., \& McAngus, C. (2015). The future of social policy in Scotland: Will further devolved powers lead to better social policies for disabled people? The Political Quarterly, 86(2), 234-239.

Salamon, L. M., \& Sokolowski, S. W. (2016). Beyond nonprofits: Re-conceptualizing the third sector. VOLUNTAS: International Journal of Voluntary and Nonprofit Organizations, 27(4), 1515-1545.

Saldaña, J. (2013). The coding manual for qualitative researchers (2nd ed.). Thousand Oaks, CA: SAGE Publications.

Scott, G., \& Wright, S. (2012). Devolution, social democratic visions and policy reality in Scotland. Critical Social Policy, 32(3), 440-453. doi:10.1177/0261018312444420.

Scottish Executive (2003). A review of the scottish executive's policies to promote the social economy. Edinburgh: Scottish Executive.

Scottish Executive (2007). Better business: A strategy and action plan for social enterprise in Scotland. Edinburgh: Scottish Executive. http://www.senscot.net/docs/betterbusinessastrategyandactionguidefor. pdf.

Scottish Government (2008). Enterprising third sector action plan 2008-2011. Edinburgh: Scottish Government. http://www.scotland.gov.uk/Publications/2008/06/19085003/0.

Scottish Government (2015). Scotland's economic strategy. Edinburgh: Scottish Government. http:// www.gov.scot/Resource/0047/00472389.pdf.

Scottish Government (2016). Internationalising social enterprise: A strategy for Scotland. Edinburgh: Scottish Government. http://www.gov.scot/Publications/2016/09/3750.

Seanor, P., \& Meaton, P. (2008). Learning from failure, ambiguity and trust in social enterprise. Social Enterprise Journal, 4(1), 24-40.

Sinclair, S., \& McKendrick, J. H. (2012). From social inclusion to solidarity: Anti-poverty strategies under devolution. In G. Mooney \& G. Scott (Eds.), Social justice and social policy in Scotland (pp. 61-80). Bristol: Policy Press.

Social Value Lab (2015). Social enterprise in Scotland: Census 2015. Edinburgh: Social Enterprise Scotland. http://www.socialenterprisescotland.org.uk/files/1a891c7099.pdf. Accessed: 16 December 2015.

Sutherland, V., McTier, A., Glass, A., \& McGregor, A. (2015) Analysis of the impact and value of community benefit clauses in procurement. Training and Employment Research Unit (TERU), University of Glasgow. http://eprints.gla.ac.uk/109821/1/109821.pdf.

Teasdale, S. (2012). What's in a name? Making sense of social enterprise discourses. Public Policy and Administration, 27(2), 99-119.

The Scotsman (2014). Scottish independence: John Swinney Hails Norway. http://www.scotsman.com/ news/politics/top-stories/scottish-independence-john-swinney-hails-norway-1-3300038. 